\title{
A Note About the Cover Art
}

Give Us Opportunities, 2016

Artist: Tee

Digital Print

Performing Statistics is a cultural organizing project that uses art to model, imagine, and advocate for alternatives to youth incarceration. Every summer, the project creates art with a group of teens in the Richmond Juvenile Detention Center's post-dispositional program about their experiences navigating the justice system and their vision for a world without youth prisons. The artwork is then produced in a number of ways in order to reach decision-makers in the education, law enforcement, and juvenile justice systems. The project's ethos looks to young people impacted by the juvenile justice system as experts society should listen to when considering policies that most impact them. Give Us Opportunities was created in the summer of 2016 and speaks to the kinds of investments young people would like to see to keep them out of the system. Jobs, credible messenger mentors, culturally competent after-school programming, more supportive educational environments, and stable housing are just a few examples of the kinds of investments that come up regularly in the project's programming. In 2020, Performing Statistics will premier No Kids in Prison, a national touring exhibition that will amplify youth justice movements across the country and weave a national narrative of youth stories, dreams, and demands. More information about the project can be found at www.performingstatistics.org. The cover art is used with permission from ART 180. 